\title{
Being a Resident in the COVID Era: It Changed Everything
}

Sir,

I was so used to the long and busy days at a bustling oncology center, starting my rounds early, preparing for the class, getting ready for the consultants rounds, and so on. And, one fine day, the coronavirus struck the world and little did we realize that everything would suddenly change. I had to be equipped with a different set of skills and methods.

Our usually very busy hospital was less crowded and looked very different. Apart from the new patients, only those who were on active anticancer treatment and the ones whose symptoms needed immediate attention were attended to. Residents along with consultants were divided into teams. From working 7 days a week and being on call $24 \mathrm{~h}$, now it became one half of the week.

As physicians, we are taught to talk to patients and examine them. With COVID looming around, social distancing became the buzz word. We had to physically distance ourselves from our patients and examine them only when it was absolutely necessary. The doctor's healing touch which was so important was forbidden now. We had to protect ourselves and our patients from the virus.

Initially, it was time-consuming to counsel the patients about self-protection and hand hygiene, but I adapted to it soon. I remember one of my patients asking me whether this virus is more dangerous than cancer and I had no answer. I had to answer many phone calls from patients and their families regarding availability and access to medicines, especially morphine. After completing my duty, my thought and prayers used to be with the patients, their family members, and caregivers. I am sure this feeling must be reverberating in the mind of every person involved directly or indirectly in fighting this pandemic.

Regular classes and bedside clinics were suspended. Online platforms gave us an opportunity to attend lectures on cancer treatments in the COVID era. We miss our regular academics at the institute, but the IJMPO online lecture series every Tuesday has been a silver lining. We wait for it to be 8.30 p.m. every Tuesday like we used to do for our favorite programs on television.

Never have I seen and received so much of information on a single subject in such a short period. It is just a grim reminder that we have very little knowledge about this virus and its treatment. It is so much imbibed into my brain that every patient I examine with cough and sore throat is now COVID, unless otherwise proved.

It gives me a sense of great pride when doctors are considered like soldiers on the war front. The claps and appreciation of the public make me work with a great zeal and enthusiasm. As a Corona warrior, I have also made up my mind to work without any worry like a soldier who doesn't think of anything else except winning the battle. However, I also make sure that I am adequately prepared to protect myself and ward off the enemy.

As I await my practical exam, the COVID pandemic has taught me so many lessons. It has exposed my weakness and vulnerability, smashed my ego, and made me feel even more humble in front of the mother nature. I hope that it will pass away soon and pray that the future generations will never have to experience something like this.

I am just waiting for this lockdown to get lifted, this pandemic to get mitigated, my exams to be completed, to meet my parents and most importantly, see my patients with a smile on their face, indicating that we all have won this battle together. I wish it was just a bad dream.

I salute everyone working tirelessly to serve their nation during these difficult times.

Financial support and sponsorship

Nil.

Conflicts of interest

There are no conflicts of interest. 


\section{Rohan Tewani}

Department of Medical Oncology, Basavatarakam Indo American Cancer Hospital and Research Institute, Hyderabad, Telangana, India

\section{Address for correspondence: Dr. Rohan Tewani,}

410, Block 5, Basavatarakam Indo American Cancer Hospital and Research Institute, Road Number 10, Hyderabad - 500034.

Telangana, India.

E-mail:rohan_tewani@yahoo.com

Submitted: $12-\mathrm{Apr}-2020$

Revised: 23-Apr-2020

Accepted: 26-Apr-2020

Published: 30-May-2020
This is an open access journal, and articles are distributed under the terms of the Creative Commons Attribution-NonCommercial-ShareAlike 4.0 License, which allows others to remix, tweak, and build upon the work non-commercially, as long as appropriate credit is given and the new creations are licensed under the identical terms.

\begin{tabular}{|l|l|}
\hline \multicolumn{2}{|c|}{ Access this article online } \\
\hline Quick Response Code: & Website: \\
& www.ijmpo.org \\
\cline { 2 - 2 } & Dol: \\
\hline
\end{tabular}

How to cite this article: Tewani R. Being a resident in the COVID era: It changed everything. Indian J Med Paediatr Oncol 2020;41:161-2. 